\title{
Cardiac tamponade as presenting symptom of tuberculosis
}

\author{
Andrea Rossi Zadra, ${ }^{1}$ Paolo Ripellino, ${ }^{2}$ Nicoletta Barzaghi ${ }^{3}$
}

${ }^{1}$ Department of Anaesthesiology, AO Città della Salute e della Scienza, Turin, Italy ${ }^{2}$ Department of Neurology, University of Turin, Novara, Italy

${ }^{3}$ Department of Cardiovascular Intensive Care Unit, AO S Croce e Carle, Cuneo, Italy

\section{Correspondence to}

Dr Paolo Ripellino, pao.ripe@hotmail.it

Accepted 28 March 2015

\section{DESCRIPTION}

A middle age man was admitted to our infectious diseases department with recent weight loss, fever, dyspnoea and palpitations. Blood and urine tests showed only increased $\mathrm{C}$ reactive protein and mild anaemia. As the patient's wife was previously diagnosed with pulmonary tuberculosis (TB), we performed an interferon $\gamma$ assay (QuantiFERONTB-2), which turned out to be positive. Sputum specimens revealed the presence of Mycobacterium tuberculosis, and TB chemotherapy (isoniazid, rifampicin, pyrazinamide and ethambutol) was immediately started. A chest and abdomen CT scan could not detect pulmonary lesions, but revealed multiple masses infiltrating the right atrium and ventricle up to the outflow tract. A few days after admittance, the patient developed heart failure because of reduced right ventricle inflow, visualised by transoesophageal echocardiography and MRI (figure 1), associated with atrial fibrillation with fast ventricular response. He was transferred to the intensive care unit for mechanical ventilation, haemodynamic support with fluids and amiodarone for rate control; he eventually required urgent cardiac surgery for repair of the inflow obstruction. The histological examination of the cardiac mass resulted positive in the Ziehl-Neelsen staining, and the diagnosis of cardiac tuberculoma was made. $^{1-3}$

Recovery from cardiac impairment was slow, and the patient received antitubercular chemotherapy for a total of 6 months. At 9-month follow-up, he did not require further antiarrhythmic drugs and the cardiac MRI (figure 2) showed a single residual chronic intramural non-active lesion, without any effect on cardiac filling.

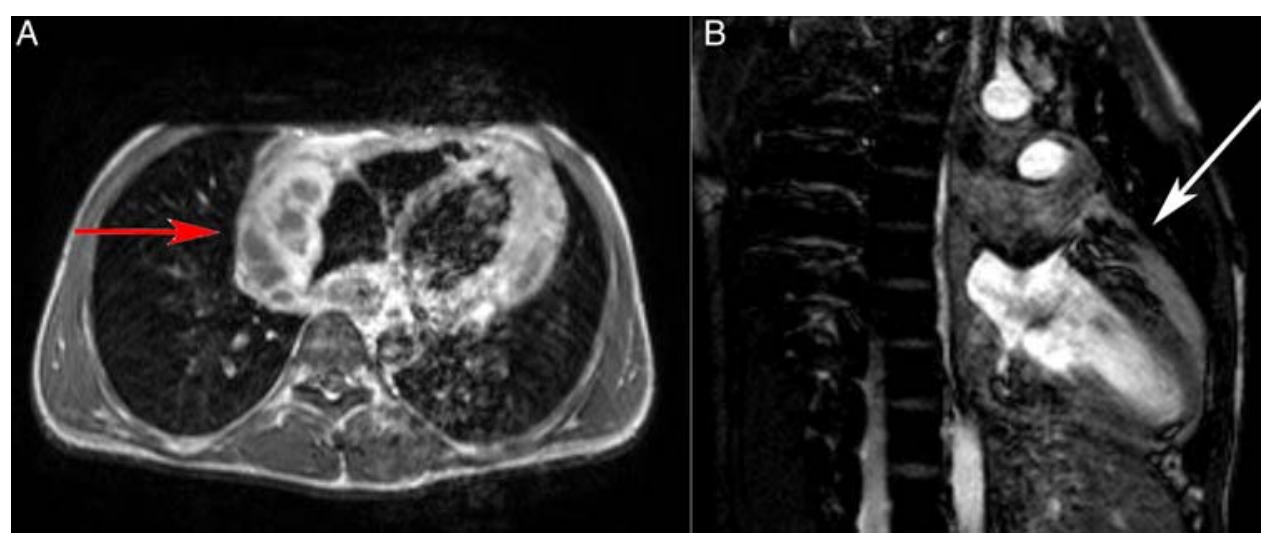

Figure 1 MRI on admittance in intensive care unit. (A) Axial T1-weighted images with gadolinium showing multiple extracardiac nodular masses located between the right atrium and the pulmonary artery, associated with pericardial effusion. Areas of marked central necrosis were surrounded by gadolinium-enhancing hypervascular lesions (red arrow). (B) Longitudinal T2-weighted images showing the involvement of the right ventricle free wall and the vena cava (white arrow).

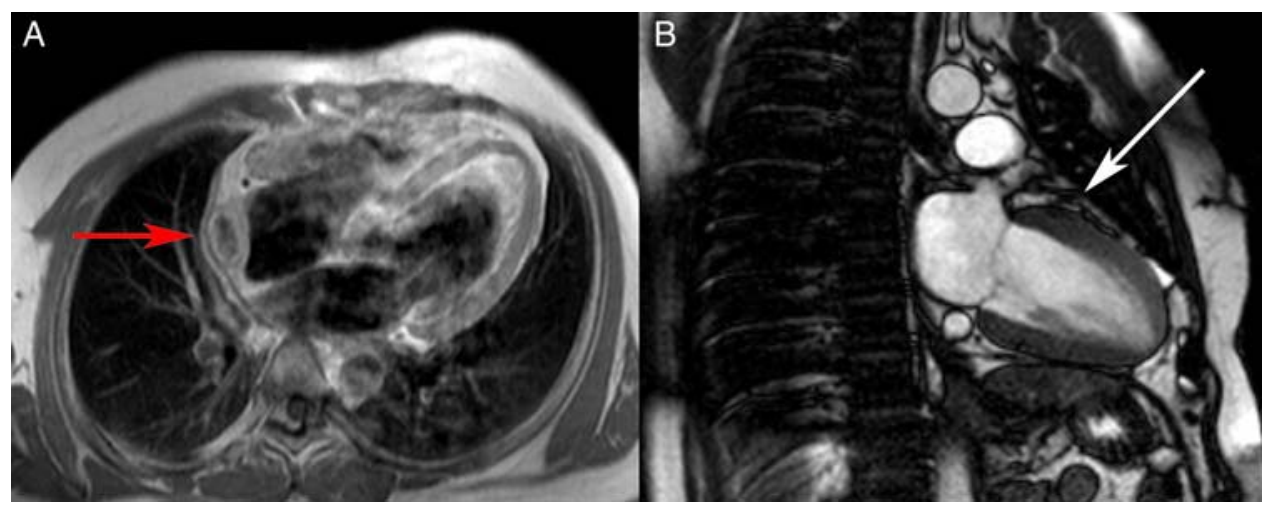

Figure 2 MRI at 9-month follow-up. Residual lesion volume was reduced and the lesion walls were stabilised in axial T1-weighted (A) and longitudinal T2-weighted images (B). 


\section{Learning points}

- Tuberculosis (TB) is a re-emerging disease that should be also considered in developed countries.

- Cardiac tamponade is an uncommon presenting symptom of $\mathrm{TB}$, but is a life-threatening condition that may require acute treatment in intensive care unit. Special precautions should be taken in this setting to avoid the spread of the disease.

- MRI may be a sensitive diagnostic test for cardiac tuberculoma, but it might require further testing for confirmation if the lesions are small.

- Contact isolation procedures in cardiac TB are mandatory; if surgery is required, all healthcare workers should also take air barrier measures to prevent infection.
Contributors ARZ, PR, NB took part in analysis of data; review of the literature; writing and editing of the paper.

Competing interests None declared.

Patient consent Not obtained.

Provenance and peer review Not commissioned; externally peer reviewed.

\section{REFERENCES}

1 Atar S, Chiu J, Forrester JS, et al. Bloody pericardial effusion in patients with cardiac tamponade: is the cause cancerous, tuberculous, or iatrogenic in the 1990's? Chest 1999;116:1564-9.

2 Afzal A, Keohane M, Keeley E, et al. Myocarditis and pericarditis with tamponade associated with disseminated tuberculosis. Can J Cardiol 2000;16:519-21.

3 Sauleda S, Permanyer MG, Soler SJ. Tuberculous pericarditis: ten-year experience with a prospective protocol for diagnosis and treatment. J Am Coll Cardiol $1988 ; 11: 724-8$.

Copyright 2015 BMJ Publishing Group. All rights reserved. For permission to reuse any of this content visit http://group.bmj.com/group/rights-licensing/permissions.

BMJ Case Report Fellows may re-use this article for personal use and teaching without any further permission.

Become a Fellow of BMJ Case Reports today and you can:

- Submit as many cases as you like

- Enjoy fast sympathetic peer review and rapid publication of accepted articles

- Access all the published articles

- Re-use any of the published material for personal use and teaching without further permission

For information on Institutional Fellowships contact consortiasales@bmjgroup.com

Visit casereports.bmj.com for more articles like this and to become a Fellow 